\title{
Parentification in late adolescence and selected features of the family system
}

\begin{abstract}
BACKGROUND
Parentification is a pattern of family interactions when either a child or an adolescent accepts roles and obligations fulfilled by adults. Being burdened with duties and taking care of parents makes separation, as well as fulfilment of development tasks and acceptance of roles suitable for a child, difficult. Simultaneously parentification might constitute a factor which forms resilience and functional coping manners. The aim of the study was to broaden the knowledge about parentification and its connections with the features of the family system.
\end{abstract}

\section{PARTICIPANTS AND PROCEDURE}

The participants were 89 people divided into triads including the youngster in his/her late teens and his/her parents. The youngsters filled in Hooper's Parentification Inventory and Olson's Flexibility and Cohension Scales (FACES IV), in Margasiński's adaptation, and assessed the bond with family members using a drawing scale. The parents also filled in the FACES IV, and additionally they evaluated the level of conflict intensity and tension in a partner relationship by means of a modified version of the Cantril Ladder.

\section{RESULTS}

Perception of the benefits of parentification differentiated the adolescents from well-balanced and ill-balanced families. Additionally, the stronger the bond the adolescents shared with their parents and the higher they assessed their satisfaction with family life and communications in the family, the more positive was their view of the effects of parentification. The predictor for the perception of the benefits of parentification by adolescents turned out to be the family's cohesion.

\section{CONCLUSIONS}

The assessment of the functioning of the family system is essential. When, according to adolescents, the family system is functioning effectively, they can use the family resources and positively reformulate even negative experiences concerned with parentification.

\section{KEY WORDS}

parentification; late adolescence; family system balance; benefits of parentification 


\section{BACKGROUND}

Most children take care of their family members (Hooper, Doehler, \& Hannah, 2011b). However, when the amount of their responsibilities is excessive in relation to their age or when they take on adult roles and responsibilities, we call it parentification (Hooper et al., 2011b; Schier, 2014). This term means reversing roles between a parent and a child. It is a pattern of family interactions in which a child or an adolescent takes on roles and responsibilities typical for adults in his culture, whereas the authority of a parent is weakened in the family (Boszormenyi-Nagy \& Spark, 1973; Mika, Bergner, \& Baum, 1987; Hooper, 2008; Hooper, DeCoster, White, \& Voltz, 2011a; Hooper, Doehler, \& Hannah, 2011b). The discussed phenomenon is characterized by an excessive level of caring about the family members and being overwhelmed with responsibilities connected with the family. In this situation a child is providing care to his caregivers instead of being given concern and attention by them (Schier, 2010; Hooper et al., 2011b). The first researchers who described parentification were psychoanalysts such as Schmideberg or Mahler and Rabinovitch in the 19050s (after: Schier, 2014). In the 1960s and 70s parentification was examined from the family systems perspective. Minuchin (1984) showed the importance of reversing the roles in the family system, which meant including the child in the parental subsystem. In this situation, he would call that child 'a parental child', which literally means a child who is in the role of a parent in the family system. He also pointed out the negative influence of reversing the hierarchy in the family on children (Minuchin, 1984). Such children are not the rightful members of the parental subsystem and at the same time they are rejected by the siblings subsystem because of the roles they perform (Schier, 2010).

There are two types of parentification - emotional parentification and instrumental parentification (Hooper, 2008; Byng-Hall, 2008; Jurkovic, Thirkield, \& Morrell, 2001, after: Hooper et al., 2011b; Schier, 2014). Emotional parentification refers to the child catering for the emotional and social needs of the family members (Schier, 2010). Caring about parents' and siblings' emotional needs may be for instance expressed by caring about their well-being and paying attention to their moods (Hooper et al., 2011b). A child may also mediate in the conflicts between family members, care about ill members of the family, become a therapist and confidant for a parent or become a scapegoat in order to maintain homeostasis in the family system (Schier, 2010; Hooper et al., 2011b). Instrumental parentification refers to caring about the family living conditions (Hooper, 2008; Hooper \& Wallace, 2010; Schier, 2010; Hooper et al., 2011; Schier, 2014). In manifests in manual work that a child performs for his family members. In this sit- uation a child deals with keeping the house and organizing the everyday routine for his family. These activities are usually typical for adults (for instance: cleaning, doing the laundry, shopping, cooking, taking care of younger siblings and even providing for the family) (Hooper et al., 2011). Schier (2010) pays attention to the fact that both instrumental and emotional parentification may coexist.

Parentification may also be categorized according to its consequences. A review of the literature indicates two types of parentification. These are constructive (adaptive) and destructive parentification (Jurkovic, 1997; Chase, 1999, after: Schier, 2014; Hooper, 2008). Destructive parentification affects children who grow up in specific circumstances which notably expose them to reversing the roles and hierarchy in the family. These are for instance children of parents addicted to drugs or alcohol, parents affected by chronic mental or physical diseases, children of highly conflicted couples, children raised by a single parent, children from indigent families, placed in foster families, immigrants' children or children having chronically ill or disabled siblings (Schier, 2014). In such situations, parentification may be seen as an act of emotional violence, because a child overwhelmed with the roles of an adult person is not able to perform his own developmental tasks and enjoy his childhood (Schier, 2010). A child who is extremely burdened with responsibilities starts to act like an adult member of the family system and takes care of the immature parents (Wolska, 2000). When the situation overcomes the child's abilities to cope with it and exhausts its resources, it may lead to many negative consequences. The cost of performing tasks that are inappropriate to the child's or adolescent's age may be internalizing behaviours (for example depression or psychosomatic symptoms) as well as externalizing behaviours (for example behaviour or personality disorders) (Jurkovic, 1997; Byng-Hall, 2008; Hooper et al., 2011a; Hooper et al., 2011b).

Parentification may be beneficial when it gives a child space to develop self-reliance without an excessive emotional or physical burden. It is important to note the fact that the family shows its gratitude and appreciates the child's confidence. In such conditions, parentification does not necessarily have a negative influence (Schier, 2014). For example, when a child performs certain functions and roles, it may build his sense of being important, helpful and needed. It builds his sense of competence and efficacy and encourages him to apply target-focused strategies in the future (Schier, 2014). Reversing the roles between parents and children may lead to developing social competences important for building relations with people. It happens due to the fact that when children have to devote their time to someone and take care of others, they also learn responsibility and the way family members take care of each
Parentification in late adolescence 
Judyta Borchet,

Aleksandra

Lewandowska-

Walter,

Teresa Rostowska other (Gladstone, Boydell, \& McKeever, 2006; Hooper, 2008). Parentification may also contribute to being able to recover from adversities, which is called resilience. Resilience is connected with functional ways of coping, healthy psychological development as well as being able to create healthy bonds with others (Marotta, 2003; DiCaccavo, 2006; Tompkins, 2007; Hooper, 2008).

The results of research on parentification's influence on adolescent functioning are not unequivocal. It turns out that this influence is not necessarily harmful to the child's development. The research conducted by Herer and Maysless (2000) suggested that parentification is harmful to the child when it becomes a stable pattern of family relations. When parentification occurs in a short-term period and is for instance connected with a critical event in the family, it may be even helpful in the process of adaptation to change. It may happen through building child's feeling of self-competence, increasing sense of self-worth (Jurkovic, 1997; Byng-Hall, 2008) or shaping altruistic behaviour (Siegel \& Silverstein, 1994).

From the family systems perspective, reversing the roles in the family may be a symptom of the system's adaptation to its situation, for example, when there is only one parent in the family or when both parents work (Schier, 2014). Adaptation allows maintaining homeostasis in the family system (Drożdżowicz, 1994; Namysłowska, 2000). According to Minuchin's theory (1984) the parental subsystem should be at the top position of the family hierarchy and be in a position of authority. In the situation of parentification where parents are not able to fulfil their roles and responsibilities, it disturbs the family hierarchy. It may happen when parents are conflicted and they include the child as a mediator in their disagreement (Schier, 2010; Hooper et al., 2011b). Minuchin (1984) also noted that reversing the roles in the family, which is a characteristic of parentification, is also a common occurrence in psychosomatic families. Psychosomatic families are those in which one of the family members suffers from a chronic disease. In such cases parentification manifests in giving physical care and emotional support to the ill family member. Apart from that, the parentification issue may affect siblings who stay together after parents' divorce. Such children often take on pseudo-parental roles (Byng-Hall, 2008). Parentification is one strategy that enables coping with separation from the parent which forms in this kind of situation.

Parentification may occur in families at any stage of family development. It also refers to those who suffer 'empty nest stage'. Adolescence is a challenge to the family system because it is a time of verifying family loyalties (Wolska, 2000). A young adult may leave the family home, build his or her first relationships and become independent, and some parents may perceive it as a threat to the family balance.
Some parents expect that their parentified child will show them loyalty by staying in the same relation as they did in childhood. It hinders the process of individuation which is specific to people at this developmental stage. This situation also preludes emotional separation from the parents as well as building close relationships outside the family of origin (Wolska, 2000). Parentification forced on a late adolescent by his family of origin may delay or disturb taking up new roles that are appropriate for the developmental stage, i.e., becoming a partner, then a spouse and finally becoming a parent (Wolska, 2000; Schier, 2010). First of all, when the late adolescent is leaving the parents on their own it may induce a feeling of guilt. That decreases the late adolescent's emotional ability to get involved in their own relationships (Wolska, 2000). Secondly, despite starting his own family, the parentified young adult may still be overburdened with the duties imposed by his parents. Because of that the young adult is not able to be fully devoted to his own family (Wolska, 2000). Apart from that, people who experienced parentification are more prone to copy this pattern in their lives and they parentify their own children (Schier, 2010). The source of this pattern lies three generations ago. It means that the parentification issue should be considered in the context of intergenerational transmission of the pattern of family functioning (Bowen, 1960; Schier, 2014 after: Chase, 1999, after: Schier, 2014). Due to this way of thinking the parents may duplicate patterns applied to them by their own parents and treat their children the same way as well as forcing certain roles on them. According to Bowen (1960) it is connected with the level of differentiation in a family which is achieved through the process of separation. People with a low level of differentiation tend to building symbiotic bonds, and they often choose a child to get involved with, especially when they are unsatisfied with a relationship with a partner. This situation limits the child's autonomy and possibility to perform the developmental task which is separation- individuation. In this way, parents also act out difficult experiences from their own past (Jurkowic, 1997; Schier, 2014), and at the same time they burden another generation. While caring for their parents, children regulate 'the debt' connected with the past traumas referring to other family members (Boszormeny-Nagy \& Spark, 1973; Jurkovic, 1997; Schier, 2010, 2014).

This research aimed to extend our knowledge about parentification and its connections with family system characteristics. Therefore, the following questions were posed:

1. Are there any differences between balanced and unbalanced family systems in terms of late adolescent's parentification intensity from the perspective of each family member?

2. Is there a connection between late adolescent's parentification intensity and quality of relation- 
ships within the family (quality of parents' partnership, strength of late adolescent's bonds with parents and siblings, quality of family communication, family life satisfaction)?

3. Which of the family system characteristics (cohesion, flexibility) has an impact on the direction (parents/ siblings) of parentification and its perceived benefits?

\section{PARTICIPANTS AND PROCEDURE}

The analysis of the empirical evidence concerned the results of 89 people. The questionnaires were presented to the family triads including the late adolescent and both his or her parents. Unfortunately, 4 fathers among 31 families refused to take part in the research. Therefore, the research group was divided into three subgroups: mothers $(n=31)$, late adolescents $(n=31)$ and fathers $(n=27)$. Families that took part in the research were homogeneous in terms of the type of parents' relationship (29 of 31 pairs were married) as well as family structure $(83.90 \%$ - full families, $6.50 \%$ - stepfamilies, $9.70 \%$ - single-parent families). The families were recruited through inviting the students, and afterwards those who agreed were given a set of questionnaires for the family. Of the 100 sets of questionnaires distributed, 31 were returned to the researchers.

Most of the late adolescents were students residing in the Tricity (Gdańsk-Gdynia-Sopot), whereas their parents lived in various regions of Poland. There were five pairs of siblings, five only children and 16 people who had siblings (who did not participate in the research) taking part in the research. Therefore, there were siblings, people who have siblings and only children tested. Late adolescents were from 18 to 25 years old $(M=22.58, S D=1.52)$. The group consisted of 20 women and 11 men. The majority of the late adolescent group were during their university studies $(83.90 \%)$. The rest of them had secondary $(9.70 \%)$ and higher education $(6.50 \%)$. In the group of late adolescents who had siblings $35.50 \%$ of them were the youngest sibling, $12.90 \%$ were middle children and $35.50 \%$ were the eldest sibling. Five members of the group did not have any siblings, which was taken into consideration when counting the results of the Sibling-focused Parentification (SFP) Subscale. There are many ways of understanding the periodization of human development. Late adolescence is defined as the period between 16 and 20 years old (Obuchowska, 2000), whereas early adulthood is from $20-23$ to 35-40 years old (Gurba, 2000). Adolescence in Levinson's classification is called the 'transitional period' and lasts from 10-12 to 20-22 (after: Brzezińska, 2000). Despite many attempts to define the moment when a person becomes mature, it is still difficult to do it (Gurba, 2000). It may be connected with certain life events such as marriage, becoming a parent or achieving economic independence (Gurba, 2000). The authors decided to use the economic criterion due to the fact that most of the tested people (aged from 18 to $25 ; M=22.58, S D=1.52)$ were students $(83.90 \%)$. It means that they were people who achieve adulthood later than their peers who started working just after a few years of apprenticeship (Gurba, 2000). The economic criterion allowed the authors to define this subgroup as 'late adolescents'.

The late adolescents' mothers were aged from 42 to 60 years old $(M=49.58, S D=5.14)$. Most of them had higher education $(58.10 \%)$. The rest of them had secondary $(32.30 \%)$ or vocational $(9.70 \%)$ education.

In the case of fathers the age range was from 44 to 60 years old $(M=51.04, S D=5.32)$. In the group of late adolescents' fathers most of them had secondary education (46.40\%). The group also included higher educated $(32.10 \%)$ men and those who had vocational education $(21.40 \%)$. Three fathers did not provide information about their education.

The adolescents participating in the research filled in an experimental version of the Polish adaptation of Hooper's Parentification Inventory made by Lewandowska-Walter, Borchet and Szpuła and the Polish adaptation of Olson's Flexibility and Cohesion Evaluation Scales prepared by Margasiński (2009) (Skale Oceny Rodziny - SOR), and they estimated their relationships with family members using the drawing scale consisting of seven pictograms (two symmetrical circles overlapping in different ways - one of them symbolized the late adolescent and the second one symbolized a parent or siblings). The first pictogram indicated a lack of ties and distance in a relationship between the late adolescent and his family member, whereas the last one indicated a strong, symbiotic bond with a parent or the family.

The parents also filled in Flexibility and Cohesion Evaluation Scales. Additionally, they evaluated the level of conflict and tension in their relationship with the partner using Cantril's ladder (1965) in its modified version (see McDowell, 2010).

The research used Kwestionariusz Parentyfikacji (KP), which is an experimental version of the Polish adaptation of an American tool called Parentification Inventory (PI) by Hooper (2009) and Hooper et al. (2011b). This questionnaire enables us to estimate the level of parentification retrospectively (Hooper et al., 2011b). The questionnaire is aimed at adults. People aged from 19 to 48 years old took part in the research conducted to validate the test (Hooper, 2011). Its theoretical base rests on family systems theory (Hooper et al., 2011b). The test contains 22 items scored from 1 to 5 , where 1 means never true, 2 is rarely true, 3 means sometimes true, 4 means often true and 5 is always true. The higher are the results achieved by the tested person in each subscale, the
Parentification in late adolescence 
Judyta Borchet,

Aleksandra

Lewandowska-

Walter,

Teresa Rostowska higher is the intensity of a certain type of parentification and its perceived benefits. There are three coherent factors:

1. Parent-focused Parentification - PFP (Parentyfikacja skupiona na rodzica), which captures adultlike roles and responsibilities that the child directs toward parents (Hooper et al., 2011b). The sample items of this scale are: I helped my parent(s) make important decisions, My parent(s) often shared secrets with me about other family members.

2. Sibling-focused Parentification - SFP (Parentyfikacja skupiona na rodzeństwo), which captures adult-like roles and responsibilities that the child directs toward his own siblings (Hooper et al., 2011b). The sample items are: I was expected to comfort my sibling(s) when they were sad or having emotional difficulties, I was the primary person who disciplined my siblings.

3. Perceived Benefits of Parentification - PBP (Postrzegane korzyści parentyfikacji). It consists of positive feelings and thoughts that come from carrying out adult-like roles and responsibilities in the family (Hooper et al., 2011). The sample items are: I felt appreciated by my family, I felt like our family was a team and worked well together.

Before starting work on the Polish adaptation, the Polish team asked Hooper for her permission to do it. In the present study the first version of the tool that is being adapted to Polish conditions was used and obtained sufficient reliability estimates $(\alpha=.75$ - Parent-focused Parentification, $\alpha=.60$ - Sibling-focused Parentification, $\alpha=.89-$ Perceived Benefits of Parentification).

Skale Oceny Rodziny (SOR) is a Polish adaptation of the American questionnaire FACES IV (Flexibility and Cohesion Scales) by Olson (adapted by Margasinski, 2009). It is a tool that investigates perception of each member of the family. Its theoretical base is Olson's Circumplex Model (Olson, 2000; Gorall, Tiesel, \& Olson, 2004; Margasiński, 2006, 2009). It describes the family upon identifying the main variables relating to their life such as Cohesion, Flexibility, Communications between family members and Satisfaction with their family life. The questionnaire consists of 62 items forming 8 scales. These scales are two Balanced Scales (Balanced Cohesion and Balanced Flexibility), four Unbalanced Scales (Disengaged and Enmeshed for the Cohesion dimension and Rigid and Chaotic for the Flexibility dimension) and two evaluative ones. The Communication and Family Life Satisfaction scales help to sum up the profile. Each item in the questionnaire scores from 1 to 5 . The test enables one to calculate the results of each scale as well as complex indicators (Balanced/Unbalanced Ratio Score, which reveals the level of function/dysfunction of the family system) (Margasiński, 2009).

The Skale Oceny Rodziny Balanced/Unbalanced Ratio Score (main rate) was used in order to answer the first research question which concerned differences between balanced and unbalanced family systems in terms of late adolescent's parentification intensity from the perspective of each family member. The main rate describes family functioning as healthy, balanced system or unbalanced family system in which dysfunctions occur. A main rate higher than 1 shows that the system is balanced, while a rate lower than one shows lack of balance. A value equal to zero indicates the most unbalanced system (Margasiński, 2009). The Balanced/Unbalanced Ratio Score was taken as a criterion to divide the studied group into balanced and unbalanced family systems and was used to answer the first research question.

\section{RESULTS}

Table 1 shows the results concerning the intensity of parentification towards a parent and siblings as well as the resulting perceived benefits for adolescents from two groups of family systems - balanced and unbalanced. Only in the area of Sibling-focused Parentification were differences uncovered between males and females in the systems studied. In the two remaining subscales no significant differences were found. Consequently, further results of our research are presented without a breakdown by gender.

Based on the results obtained, one can conclude that adolescents from the two family types do not differ in terms of intensity of parentification directed at a parent and siblings. This means that in the assessment of a late adolescent he or she is burdened with responsibilities, including those assigned to adult family members, to a similar extent regardless

Table 1

Parentification of late adolescents from balanced and unbalanced family systems - adolescents' perception

\begin{tabular}{|c|c|c|c|c|c|c|}
\hline & \multicolumn{2}{|c|}{$\begin{array}{c}\text { Balanced family } \\
\text { systems }\end{array}$} & \multicolumn{2}{|c|}{$\begin{array}{c}\text { Unbalanced family } \\
\text { systems }\end{array}$} & \multirow[t]{2}{*}{$t$} & \multirow[t]{2}{*}{$p$} \\
\hline & $M$ & $S D$ & $M$ & $S D$ & & \\
\hline Parent-focused Parentification & 26.33 & 4.94 & 26.42 & 7.70 & -0.04 & .972 \\
\hline Sibling-focused Parentification & 15.50 & 4.48 & 15.58 & 2.50 & -0.06 & .950 \\
\hline Perceived Benefits of Parentification & 12.17 & 2.37 & 8.74 & 3.30 & 3.12 & .004 \\
\hline
\end{tabular}


of how proper the functioning of the family is in his or her perception. The factor that differentiates adolescents from balanced and unbalanced family systems can be found in the perception of the resulting benefits $(p=.004)$. As it turns out, young people being raised in families that are properly functioning in terms of closeness and of the ability to adjust to development changes and changes coming from outside the system have more positive thoughts and feelings regarding potentially assuming responsibilities such as taking care of parents or siblings.

Further analyses (Table 2 and Table 3) were carried out in order to assess whether the intensity of parentification and of the resulting benefits perceived by the adolescent differs depending on the perception of the family system by mothers and fathers. In no dimension of parentification, either regarding mothers or fathers of late adolescents, were statistically significant results obtained. A single result on the level of statistical trend in the area of parentification focused on a parent - in systems unbalanced in the father's perception, adolescents may feel to a larger extent overburdened by responsibilities related to taking care of parents and taking over responsibilities assigned to the adults of the family.

Another group of analyses aimed at determining the connections between the parentification and the quality of family relations understood as the quality of the adolescents' parents' partnership relation, the strength of his or her bond with parents and siblings,

Table 2

Parentification of late adolescents from balanced and unbalanced family systems - mothers' perception

\begin{tabular}{lccccccc}
\hline & \multicolumn{3}{c}{$\begin{array}{c}\text { Balanced family } \\
\text { systems }\end{array}$} & \multicolumn{2}{c}{$\begin{array}{c}\text { Unbalanced family } \\
\text { systems }\end{array}$} & $t$ & \\
\cline { 2 - 5 } & $M$ & $S D$ & $M$ & $S D$ & & \\
\hline Parent-focused Parentification & 27.51 & 5.63 & 25.41 & 7.45 & 0.89 & .379 \\
Sibling-focused Parentification & 16.21 & 3.66 & 15.00 & 3.04 & 1.01 & .321 \\
Perceived Benefits of Parentification & 10.36 & 3.63 & 9.82 & 3.26 & 0.43 & .670 \\
\hline
\end{tabular}

Table 3

Parentification of late adolescents from balanced and unbalanced family systems - fathers' perception

\begin{tabular}{lcccrrrr}
\hline & \multicolumn{2}{c}{$\begin{array}{c}\text { Balanced family } \\
\text { systems }\end{array}$} & \multicolumn{2}{c}{$\begin{array}{c}\text { Unbalanced family } \\
\text { systems }\end{array}$} & $t$ & & \\
\cline { 2 - 5 } & $M$ & $S D$ & $M$ & $S D$ & & \\
\hline Parent-focused Parentification & 24.20 & 5.16 & 28.44 & 7.41 & -1.84 & .080 \\
Sibling-focused Parentification & 15.93 & 3.08 & 15.19 & 3.62 & 0.62 & .543 \\
Perceived Benefits of Parentification & 10.07 & 3.81 & 10.06 & 3.07 & $<0.01$ & .997 \\
\hline
\end{tabular}

Table 4

Correlation between late adolescents' parentification and quality of the relationship within the family - marital conflict and family bonds

\begin{tabular}{lccc}
\hline Variables & $\begin{array}{c}\text { Parent-focused } \\
\text { Parentification }\end{array}$ & $\begin{array}{c}\text { Sibling-focused } \\
\text { Parentification }\end{array}$ & $\begin{array}{c}\text { Perceived Benefits } \\
\text { of Parentification }\end{array}$ \\
\hline $\begin{array}{l}\text { Marital conflict } \\
\text { (mothers' perception) }\end{array}$ & -.02 & -.17 & $-.37^{*}$ \\
$\begin{array}{l}\text { Marital conflict } \\
\text { (fathers' perception) }\end{array}$ & -.02 & -.17 & -.13 \\
$\begin{array}{l}\text { Bonds with mother } \\
\text { (adolescents' perception) }\end{array}$ & .07 & -.15 & $.49^{* *}$ \\
$\begin{array}{l}\text { Bonds with father } \\
\text { (adolescents' perception) }\end{array}$ & -.08 & -.20 & $.64^{* * *}$ \\
$\begin{array}{l}\text { Bonds with siblings } \\
\text { (adolescents' perception) }\end{array}$ & .17 & .34 & .27 \\
\hline $\begin{array}{l}\text { Note. }{ }^{* * *} p<.001,{ }^{* *} p<.01,{ }^{*} p<.05 \\
\end{array}$ & & &
\end{tabular}


Table 5

Correlation between late adolescents' parentification and quality of the relationship within the family - family communication and family life satisfaction

\begin{tabular}{lccc}
\hline Variables & $\begin{array}{c}\text { Parent-focused } \\
\text { Parentification }\end{array}$ & $\begin{array}{c}\text { Sibling-focused } \\
\text { Parentification }\end{array}$ & $\begin{array}{c}\text { Perceived Benefits } \\
\text { of Parentification }\end{array}$ \\
\hline $\begin{array}{l}\text { Family communication } \\
\text { (adolescents' perception) }\end{array}$ & -.03 & -.07 & $.73^{* * *}$ \\
$\begin{array}{l}\text { Family communication } \\
\text { (mothers' perception) }\end{array}$ & .02 & -.04 & .20 \\
$\begin{array}{l}\text { Family communication } \\
\text { (fathers' perception) }\end{array}$ & .14 & .03 & $.40^{*}$ \\
$\begin{array}{l}\text { Family life satisfaction } \\
\text { (adolescents' perception) }\end{array}$ & -.00 & -.01 & $.76^{* * *}$ \\
$\begin{array}{l}\text { Family life satisfaction } \\
\text { (mothers' perception) }\end{array}$ & .17 & .01 & .24 \\
$\begin{array}{l}\text { Family life satisfaction } \\
\text { (fathers' perception) }\end{array}$ & & .02 & .02 \\
\hline
\end{tabular}

Note. ${ }^{* * *} p<.001,{ }^{* *} p<.01,{ }^{*} p<.05$

Table 6

Cohesion and flexibility of family system as predictors of Perceived Benefits of Parentification

\begin{tabular}{llcc}
\hline $\begin{array}{l}\text { Family system features as predictors } \\
\text { of Perceived Benefits of Parentification }\end{array}$ & $\beta$ & $R^{2}$ & $F(d f)$ for $R^{2}$ \\
\hline Cohesion & $.63^{* *}$ & .58 & 19.44 \\
Flexibility & .15 & $(2,100)^{* * *}$ \\
\hline
\end{tabular}

Note. ${ }^{* * *} p<.001,{ }^{* *} p<.01,{ }^{*} p<.05$

the quality of communication in the family and the general satisfaction with family life.

The results presented in Tables 4 and 5 suggest yet again significant links between the perceived benefits of the parentification which can be felt by a late adolescent and the quality of relations in the family in which they are raised. The strongest correlations were observed in the case of the adolescent's bond with the father as well as of the quality of communication in the family and the satisfaction from the functioning of the family. It turns out that the closer the relation between the young person and the father, and the greater his or her satisfaction with the communication among family members and problem solving within the family as well as with family life in general, the better can such an adolescent perceive positive aspects of potential assumption of responsibilities of adult family members in the relation with parents and siblings. Weaker, but also statistically significant correlation indicators were found in the field of the adolescent's bond with the mother - the more coherent this bond is in the child's assessment, the more positive thoughts and feelings the child has when he or she takes over responsibilities of the parent. The weakest connection was observed in the case of the mother's assessment of the quality of the partnership relation and its connection with the perception of benefits from parentification by the adolescent - the more marred by conflicts the partners' relation is in the woman's assessment, the fewer positive aspects of assuming adult roles the child perceives. A correlation of a similar strength applies to the communication in the family in the father's assessment and the benefits from taking over tasks assigned to parents in the family in the adolescent's perception. This is a positive connection - the higher the quality of communication among family members in the father's assessment, the more parentification benefits the adolescent perceives.

At the last stage of statistical analyses, it was investigated which features of the family system may constitute a predictor of directing parentification and of the parentification benefits perceived by the adolescent. To this aim, a regression analysis was conducted. Regression models for parentification focused on a parent and siblings, where the system cohesion and flexibility indicators were independent variables, were not statistically significant. Below, results are presented for the dependent variable Perceived Benefits of Parentification (Table 6). 
The general model which takes into account the family system cohesion and flexibility indicators turned out to be significant for making predictions about the extent to which the adolescent perceives the positive aspects of taking over parental roles in the family. The feature of the system which constitutes the predictor for perception of parentification benefits by late adolescents is the cohesion of the family. The stronger the child at this stage of individual development and at the stage of leaving the family home feels that family members have close relations to one another, the more positively he or she responds to situations in which he or she needs to take over parental responsibilities. In contrast, flexibility does not constitute a significant predictor for perceived benefits of parentification.

\section{DISCUSSION}

The aim of this study is to broaden the knowledge about parentification experienced by an adolescent in his/her late teens, the way he/she perceives it and at whom he/she targets it, as well as the connection between parentification and the selected features of the family system.

The first question was concerned with the differences between balanced and unbalanced family systems in the area of parentification features (parent-focused, sibling-focused, the benefits of parentification which are noticed) which occur in the case of a late adolescent from the perspective of each family member. Statistically significant results were obtained only for the variable 'the benefits of parentification' which are noticed only in the case when the functioning of the system was evaluated by adolescents. No statistically significant results were obtained in regard to parentification features in the case of a late adolescent in the case when the balance of the family system was assessed by mothers and fathers. The results indicate that adolescents from balanced systems make more use of parentification. Then they can experience the factors which contribute to the acquisition of stress coping skills and the development of effective strategies for handling emotions during a crisis situation (Hooper, 2007; Gladstone et al., 2006; Hooper, 2008). In an attempt to, on the one hand, carry out a synthesis of experiences burdening the child, and on the other hand, of the advantages connected with taking care of another person, Hetherington (2003) suggested that parentification favours the development of 'competence at a cost'. Therefore, the results of the original studies can refer to the adaptation function of parentification - individually for the adolescent, but also for his/her family - as well as to the posttraumatic growth and development of individual resources in the form of resilience as the consequences of difficult experienc- es related to the necessity to take over adults' duties in childhood (see Hooper, Marotta, \& Lanthier, 2008). The obtained result is also consistent with the guidelines of the Olson Circumplex Model and the Family Stress Model by Carter and McGoldrick, according to which balanced families cope better with stressors and emotional tension resulting from both internal changes (e.g. moving on to another phase of the family life cycle, the parent's illness) and external changes (e.g. either parent losing his/her job) (Carter \& McGoldrick, 1989; Olson, 2004; Margasiński, 2006, 2009). Therefore, one can predict that adolescents raised in balanced systems develop constructive strategies for coping with parentification. They can also reformulate it positively and notice self-development benefits for themselves.

In the analysis serving to provide the answer to the second question, it was verified whether the quality of relationships in the family (defined as the quality of the parents' partner relationship, the strength of bonds with parents and siblings, the quality of communications in the family, and satisfaction with family life) is connected with the type and intensity of parentification experienced by the adolescent. It was found that the stronger the mother assessed the level of her conflict with her partner, the fewer advantages of parentification a late adolescent noticed. Although the fathers' assessment of the conflict in the relationship with their partners was not statistically significant, the results concerning the assessment of mothers indicate that a conflict in the family subsystem make it difficult for the adolescent to make use of family resources. The children raised by conflicted couples are more endangered to negative consequences of parentification (Schier, 2014), and therefore they can notice fewer potential benefits. This result is consistent with the system theory and shows that the parental subsystem is the most important subsystem in the family. It occupies the top place in the hierarchy and the relationships within it constitute the foundation of the entire system (Minuchin, 1984; Satir, 2000), and the emotional atmosphere created by adults is a 'secure family base' (Byng-Hall, 2002). When there are anomalies in the couple in the form of a conflict, the child, focusing cognitively on the family crisis and sometimes trying to solve it, as well as being burdened with his/her parents' emotional problem, has fewer opportunities to use family resources, which indirectly limits his/her self-development. Through observation, young people learn from their parents how to functionally solve conflicts (Pryor \& Pattison, 2007). Lack of such patterns makes it difficult to acquire constructive ways of conflict solving and to form correct manners of communicating (see Harwas-Napierała, 2008). The study results also indicated that the stronger the bond was between the adolescent and both of his/her parents, the more sig-
Parentification in late adolescence 
Judyta Borchet,

Aleksandra

Lewandowska-

Walter,

Teresa Rostowska nificant were the advantages of parentification he/ she noticed. This result is consistent with the studies which have been conducted so far. Tompkins' study (2007), whose participants were children and adolescents living with a parent in a serious health condition, indicated that emotional parentification strengthens the closeness between the parent and the child and has a positive influence on the child raising process and his/her adaptation to an illness in the family. Perhaps, in such a situation, the child wishes to take care of the sick parent and the time spent in such a way influences their mutual bond. The child does not want to cause his/her parents any educational problems, and assistance and an opportunity to be active make it easier for him/her to come to terms with the adult's illness and to adapt to a crisis situation in the family. Similarly, adolescents who perceive the bond with their parents as strong could experience emotional parentification, which brought them closer. It is thanks to this closeness that the adolescent noticed more advantages of parentification. The connection between parentification and the communication between family members was confirmed only when the communication was assessed by adolescents in their late teens and their fathers. The better they assessed the quality of communication in the family, the more advantages adolescents noticed. The result is consistent with the assumptions of the Olson Circumplex Model, because communication, as the auxiliary dimension, moderates the level of cohesion and flexibility in the system, indirectly influencing its balance (Olson, 2004; Margasiński, 2009). Additionally, the more satisfied adolescents were with their family life, the more positively they assessed the consequences of parentification in their life. Satisfaction with their family life is the extent to which family members are fulfilled and happy with each other (Olson, 2004; Margasiński, 2009). Therefore, the obtained result suggests that adolescents who are satisfied with their family life are more inclined to positively reformulate parentification experienced by them and to notice more benefits connected with it.

The third question was concerned with the features of the family system - cohesion and flexibility as predictors for the direction of parentification and perception of its advantages. Directing parentification behaviour to parents or siblings did not depend, at a statistically significant level, on flexibility and cohesion of the family system assessed by all the family members. However, cohesion and flexibility of the family system proved to be significant predictors for the observed advantages of parentification in the case when the features of the family system were evaluated by adolescents in their late teens. After a more thorough analysis it was found that it is the cohesion of the family system that is the most important in the model and influences the perception of the advantages connected with parentification. This result can be interpreted in two ways. Firstly, a high level of closeness between family members forces adolescents to take care of their parents, often with too much effort compared to their strength and to a degree not suited to their developmental possibilities. In such a situation they reformulate negative experiences into positive ones, perhaps in order to protect themselves from negative consequences of parentification and confusion with family members. What makes it possible for them is resilience, developed at the earlier stages, and in the case of adolescents in their late teens, a certain level of personal maturity which they have already reached. On the other hand, the expression of parentification behaviour towards their parents can form the adolescent's sense of agency, competence and responsibility and enhance his/her self-assessment. The adolescent feels needed, important and helpful, which makes him/her notice numerous advantages of parentification and consequently strengthens his/her personal resources (see Hooper et al., 2008; Schier, 2014). Hence, he/she continues behaviour connected with parentification, and instrumental help and emotional support for his/her parents improve the bond between the adolescent and his/her family.

Taking all this into consideration, directing parentification behaviour to either parents or siblings is not connected with the way the adolescent assesses the balance of the system, the intensity of the conflict between parents, or the quality of bonds and communication between the adolescent and the family members. Perhaps there are other features of the family system which are connected with the direction of parentification behaviour, and it requires further research. However, it was possible to determine that the better is the adolescent's assessment of the functioning of the family system, the more positive consequences the adolescent notices which refer to taking over the parents' responsibilities and channelling them to adult family members and siblings. Despite parentification, which is a dysfunction, occurring in the family, the system can remain balanced thanks to the fact that adolescents are able to make use of the advantages of this process and in this way to balance the family, which would be consistent with the assumptions of the family system theory (see von Bertalanffy, 1984; de Barbaro, 1999). This result is also consistent with the studies whose results show that parentification can favour immunity towards misfortunes, that is resilience (see Hooper, 2008). It leads to the development of functional coping mechanisms, a healthy mental growth and the ability to form proper emotional bonds, also at later development stages (see DiCaccavo, 2006; Marotta, 2003; Tompkins, 2007; Hooper, 2008). Therefore, one can see that when the family system works efficiently, adolescents can make use of it and apply 
family resources, as well as reformulating possible negative experiences connected with parentification. However, one should consider whether the strength of the bond with the parents or siblings and the cohesion of the entire system, which proved to be a significant predictor for the perception of advantages of parentification, always means that there are correct relationships between the family members. Strong bonds do not always equal correct relationships, and if they are too close, there might be fear involved (see Bowen, 1960), also connected with potential changes in the system. These are the features of family systems defined by Minuchin (1967) as enmeshed families, which tend to maintain a façade of the family's positive image and their own functioning in it. Strict boundaries of the family system, which are blurred between family members (Minuchin, 1984), and enmeshed bonds (Olson, 2004) might make it difficult for the adolescent to notice the limitations in his/her self-growth that are connected with his/her sacrifices for the family.

Therefore, in the interpretation of the obtained results one should also take into account the aspect of the human being's individual development. In the case of parentification, the age of the person experiencing it is of significance, since the earlier it occurs, the more serious the consequences are for the self-development (Schier, 2010). For instance, young children do not possess sufficient resources to cope with the situation of reversed roles in the family system. Although we do not know the course of parentification in the case of adolescents in their late teens who participated in the study and we do not know when it began, we can indirectly conclude, from their ability to notice positive advantages of parentification, that they have developed mental immunity and strategies for coping with the deregulation of the hierarchy in the family. It may be connected with resilience that they have already acquired, which helped them to work out and reformulate childhood experiences. As shown by the studies on the formation of resilience which have been conducted so far, individual factors can be more significant in this process than social ones (see Ogińska-Bulik \& Kobylarczyk, 2015). Simultaneously, similarly to what has been discussed above, one should take into consideration strong family bonds and execution of the roles fulfilled by adult members of the system as a factor which can hinder correct processes of the adolescent's separation-individualization, and in the future it can cause that the adolescent will separate emotionally from too burdening childhood experiences (see Bowen, 1960). A strong bond and loyalty towards the family, which can be both a source and effect of parentification, and consequently even the trait of 'compulsive caretaking' (see Nuttal, Valentino, \& Borkowski, 2012), can also constitute a factor which will make it harder for a given person to ac- cept roles - to establish an intimate relationship (see Macfie, McElwain, Houts, \& Cox, 2005), or to accept the role of a parent (see Shaffer \& Egeland, 2011; Nutall et al., 2012).

\section{REFERENCES}

Bertalanffy von, L. (1984). Ogólna teoria systemów [General System Theory]. Warszawa: PWN.

Bank, S. (1992). Remembering and reinterpreting sibling bonds. In F. Boer \& J. Dunn (eds.), Children's sibling relationships: Developmental and clinical issues (pp. 139-163). New Jersey: Erlbaum.

Barbaro de, B. (1999). Wprowadzenie do systemowego rozumienia rodziny [Introduction to systemic understanding of families]. Kraków: Wydawnictwo UJ.

Boszormeny-Nagy, I., \& Spark, G. (1973). Invisible loyalties. New York: Harper and Row.

Bowen, M. (1960). The family as the unit of study and treatment. American Journal of Orthopsychiatry, $31,40-60$.

Byng-Hall, J. (2002). Relieving parentified children's burdens in families with insecure attachment patterns. Family Process, 41, 375-388.

Byng-Hall, J. (2008). The significance of children fulfilling parental roles: implications for family therapy. Journal of Family Therapy, 30, 147-162.

Brzezińska, A. (2000). Spoteczna psychologia rozwoju [Social developmental psychology]. Warszawa: Wydawnictwo Naukowe Scholar.

Cantril, H. (1965). The patterns of human concerns. New Brunswick: Rutgers University Press.

Carter, B., \& McGoldrick, M. (1989). Overview: the changing family life cycle - a framework for family therapy. In B. Carter \& M. McGoldrick (eds.), The Changing Family Life Cycle - A Framework for Family Therapy (pp. 3-28). Boston-London-Sydney-Toronto: Allyn and Bacon.

DiCaccavo, A. (2006). Working with parentification: Implications for clients and counselling psychologists. Psychology and Psychotherapy: Theory, Research, and Practice, 79, 469-478.

Drożdżowicz, L. (1994). Ogólna teoria systemów [General systems' theory]. In B. de Barbaro (ed.), Wprowadzenie do systemowego rozumienia rodziny [Introduction to systemic understanding of families] (pp. 9-17). Kraków: Collegium Medicum UJ.

Gladstone, B. M., Boydell, C. M., \& McKeever, P. (2006). Recasting research into children's experiences of parental mental illness: Beyond risk and resilience. Social Science and Medicine, 62, 2540-2550.

Gorall, D. M., Tiesel, J., \& Olson, D. (2004). FACES IV: Development and validation. Minnesota: Life Innovations, Inc.

Gurba, E. (2002). Wczesna dorosłość [Early adulthood]. In B. Harwas-Napierała \& J. Trempała
Parentification in late adolescence 
Judyta Borchet,

Aleksandra

LewandowskaWalter,

Teresa Rostowska (eds.), Psychologia rozwoju człowieka (Tom 1) [Developmental psychology (Vol. 1)] (pp. 202-233). Warszawa: Wydawnictwo Naukowe PWN.

Harwas-Napierała, B. (2008). Komunikacja interpersonalna $w$ rodzinie [Interpersonal communication within the family]. Poznan: Wydawnictwo UAM.

Hetherington, E. M. (2003). Social support and the adjustment of children in divorced and remarried families. Childhood, 10, 217-236.

Herer, Y., \& Maysless, O. (2000). Emotional and social adjustment of adolescents who show role-reversal in the family. Megamot, 40, 413-441.

Hooper, L. M. (2007). Expanding the discussion regarding parentification and its varied outcomes: Implications for mental health research and practice. Journal of Mental Health Counseling, 29, 322-337.

Hooper, L. M., Marotta, S. A., \& Lanthier, R. P. (2008). Predictors of growth and distress following childhood parentification: A retrospective exploratory study. Journal of Child \& Family Studies, 17, 693705. DOI: 10.1007/s10826-007-9184-8

Hooper, L. M. (2008). Defining and understanding parentification: implications for all counselors. The Alabama Counseling Association Journal, 34, 34-43.

Hooper, L. M. (2009). Parentification inventory (Available from L. M. Hooper, Department of Educational Studies in Psychology, Research Methodology, and Counseling, The University of Alabama, Tuscaloosa, AL. 35487).

Hooper, L. M., \& Wallace, S. A. (2010). Evaluating the parentification questionnaire: psychometric properties and psychopathology correlates. Contemporary Family Therapy, 32, 52-68.

Hooper, L. M., DeCoster, J., White, N., \& Voltz, M. L. (2011a). Characterizing the magnitude of the relation between parentification and psychopathology: A meta-analysis. Journal of Clinical Psychology, 67, 1028-1043.

Hooper, L. M., Doehler, K., \& Hannah, N. J. (2011b). The parentification inventory: development, validation and cross-validation. The American Journal of Family Therapy, 39, 226-241.

Jurkovic, G. J. (1997). Lost Childhoods: The Plight of Parentified Child. New York: Brunner-Mazel.

Lewandowska-Walter, A., Borchet, J., \& Szpuła, A. (2015). Kwestionariusz parentyfikacji (materiał niepublikowany, dostępny u autorów) [Parentification Inventory (unpublished script available from the authors)]. Gdańsk: Instytut Psychologii UG.

Macfie, J., McElwain, N. L., Houts, R. M., \& Cox, M. J. (2005). Intergenerational transmission of the role reversal between parent and child: Dyadic and family systems internal working models. Attachment \& Human Development, 7, 51-65. doi: 10.1080/14616730500039663.

Margasiński, A. (2006). Rodzina w Modelu Kołowym i FACES IV Davida H. Olsona [Family in Circum- plex Model FACES IV by David H. Olson]. Nowiny Psychologiczne, 4, 69-89.

Margasiński, A. (2009). Skale oceny rodziny SOR [Family rating scales SOR]. Warszawa: Pracownia Testów Psychologicznych Polskiego Towarzystwa Psychologicznego.

Marotta, S. A. (2003). Integrative systemic approaches to attachment-related trauma. In P. Erdman \& T. Caffery (eds.), Attachment and family systems: Conceptual, empirical, and therapeutic relatedness (pp. 225-240). New York: Taylor and Francis.

McDowell, I. (2010). Measures of self-perceived well-being. Journal of Psychosomatic Research, 69, 69-79.

Mika, P., Bergner, R. M., \& Baum, M. C. (1987). The development of a scale for the assessment of parentification. Family Therapy, 14, 229-235.

Minuchin, S. (1967). Families of the Slums. Basic Books: New York.

Minuchin, S. (1984). Families and Family Therapy. Cambridge, Massachusetts: Harvard University Press.

Namysłowska, I. (2000). Terapia rodzin [Family therapy]. Warszawa: Wydawnictwa Instytutu Psychiatrii i Neurologii.

Nuttall, A. K., Valentino, K., \& Borkowski, J. G. (2012). Maternal history of parentification, maternal warm responsiveness, and children's externalization behavior. Journal of Family Psychology, 26, 767-775.

Obuchowska, I. (2002). Adolescencja [Adolescence]. In B. Harwas-Napierała \& J. Trempała (eds.), Psychologia rozwoju człowieka (Tom 1) [Developmental psychology (Vol. 1)] (pp. 163-201). Warszawa: Wydawnictwo Naukowe PWN.

Ogińska-Bulik, N., \& Kobylarczyk, M. (2015). Resilience and social support as factors promoting the process of resilience in adolescents - wards of children's homes. Health Psychology Report, 3, 210-219. doi: 10.5114/hpr.2015.49045

Olson, D. H. (2000). Circumplex model of marital and family systems. Journal of Family Therapy, 22, 144-167.

Olson, D. H. (2004). Circumplex Model VII: Validation Studies and FACES III. Family Process, 25, 337-351. doi: 10.1111/j.1545-5300.1986.00337.x

Pryor, J. E., \& Pattison, R. (2007). Adolescent's perception of parental conflict. The downside of silence. Journal of Family Studies, 13, 72-77.

Satir, V. (2000). Rodzina - tu powstaje człowiek [Peoplemaking]. Sopot: Gdańskie Wydawnictwo Psychologiczne.

Siegel, B., \& Silverstein, S. (1994). What about me? Growing up with developmentally disabled sibling. New York: Plenum Press.

Schier, K. (2010). „Gdy dziecko staje się rodzicem" - odwrócona troska, czyli zjawisko paren- 
tyfikacji w rodzinie ["When a child becomes a parent" - Reversed care, means the phenomenon parentyfikation in the family]. In B. Tryjarska (ed.), Bliskość w rodzinie. Więzi w dzieciństwie a zaburzenia $w$ dorostości [The closeness of the family. Bonds in childhood and disorders in adulthood] (pp. 63-80). Warszawa: Wydawnictwo Naukowe Scholar.

Schier, K. (2014). Doroste dzieci. Psychologiczna problematyka odwrócenia ról w rodzinie [Adult children. Psychological problems of role reversal in the family]. Warszawa: Wydawnictwo Naukowe Parentification in Scholar.

Shaffer, A., \& Egeland, B. (2011). Intergenerational transmission of family boundary dissolution: Observations and psychosocial outcomes in adolescence. Family Relations: An Interdisciplinary Journal of Applied Family Studies, 60, 290-302. doi: 10.1111/j.1741-3729.2011.00653.x

Tompkins, T. L. (2007). Parentification and maternal HIV infection: Beneficial role or pathological burden. Journal of Child and Family Studies, 16, 113-123.

Wolska, M. (2000). Rodzinna lojalność [Family loyalty]. In B. Kosek-Nita \& D. Raś (eds.), Kontakty z ludźmi 'innymi' jako problem wychowania, opieki $i$ resocjalizacji [Relations with humans 'other' as a problem of education, health and rehabilitation] (pp. 49-60). Katowice: Wydawnictwo Uniwersytetu Śląskiego. 